\title{
Expansion Mode Choices: The case of US Multinationals in Brazil
}

\author{
Juliana Carvalho Sampaio Tourinho ${ }^{1 \mathrm{~A}}$ and Hsia Hua Sheng ${ }^{\mathrm{BC}}$ \\ ${ }^{A}$ Escola de Economia de São Paulo da Fundação Getúlio Vargas - EESP/FGV, São Paulo, SP, Brazil \\ ${ }^{B}$ Escola de Administração de Empresa de São Paulo da Fundação Getúlio Vargas - EAESP/FGV, São Paulo, SP, Brazil \\ ${ }^{C}$ Escola Paulista de Política, Economia e Negócios da Universidade Federal de São Paulo - EPPEN/UNIFESP, SP, Brazil
}

\section{ARTICLE DETAILS}

\section{Article history:}

Received August 30 2016

Accepted July 10 2017

Available online in August 31 2017

Double Blind Review System

Scientific Editor

Ilan Avrichir

\section{Keywords:}

MNE

Expansion Modes

Bundling Model

Local Complementary Assets

\begin{abstract}
The traditional theory of expansion modes argue that local experience would bring Multinationals (MNEs) more knowledge of the particularities of the local market, mitigating subsequent same local expansion risk and will choose greenfield and whollyowned subsidiary. However, local complementary inputs become relevant in this expansion decision, when local complementary assets are not always available and freely negotiated (Hennart, 2009). This paper analyzes the sequential expansion decision made by 10 major and large experienced US multinationals in Brazil between 2004 and 2013, identifying the possible motives for this decision considering MNEs expansion theories and Brazilian inter-regions differences. We found evidence that supports Hennart Bundling Model: i) the experience of multinationals in Brazil not always increases multinationals' commitment in the host countries by establishment of new wholly-owned subsidiaries; ii) US MNEs make acquisitions when they need to enter in a new region with significant difference of local economic development from where MNE already operated; iii) also, Brazilian regional factors such as concentration, growth and industries' intrinsic features are determinants of acquisitions and joint ventures choices.
\end{abstract}

(C) 2017 Internext | ESPM. All rights reserved!

\section{INTRODUCTION}

One stream of research on multinational enterprises (MNE) foreign direct investment addresses how learning from previous experience conditions the likelihood of investing more subsequently. The IB literature has generally modeled these experiences from the target country and from international environment.

The Uppsala Internationalization approach argues that foreign investors with large experience of the target country will tend to prefer, ceteris paribus, wholly-owned subsidiaries (WOSs) over joint ventures (JVs) (Johanson and Vahlne, 1977). Firm's own past experiences would provide MNEs good knowledge of the best ways to access local assets, such as workforce and distribution channel. This accumulated knowledge in-house will also allow
MNEs to not need to acquire local firms in their sequential local expansion.

In none of these frameworks do local owners of complementary assets seem to play any critical role in the foreign investor's sequential local expansion decision. The preceding framework are MNE-centric entry models assuming that host countries' local assets (and their strategic advantages) are always available and are freely negotiated in the local markets. Hennart Bundling Model (Hennart, 2009), however, argue that local assets market could be inefficient, especially in Emerging markets. Consequently, expansion mode may consider local complementary inputs owners' preferences. Concentration ratio of an industry and number of suppliers have been used as proxies to measure difficulty to access local complementary assets (Hennart, Sheng and Pimenta, 2015). 
In addition, the access to the complementary assets could become more critical for foreign investor decision about the local sequential expansion, when the target country is a large continental country with significant regional differences. The purpose of this paper is therefore to analyze effects of access to local complementary inputs on the foreign investor expansion in the same target country, identifying how it affects MNEs sequential expansion decision. The Longitudinal method was applied to study transactions carried out by the 10 major US groups in Brazil between 2004 and 2013. As there are many "Brazis" within Brazil, we expect that significant regional differences will contribute to our study about necessity of Hennart's Bundling Model.

This paper contributes to the existing literature by adding regional difference within the same country to operationalize the regional imperfect market, that could be monopolized by local regional firms. This paper also contributes to the discussion of non MNEcentric theories that focus on the inefficient market implication in International Business Model.

\section{LITERATURE}

\subsection{MNE's Expansion Model}

According to traditional theories, MNEs would be willing to hold a higher stake in investees to the extent they acquire international experience, changing from entities that require the execution of contracts only (licensing and exportation) to WOS.

Local expertise would bring MNEs more knowledge of the particularities of the local market, mitigating subsequent expansion problems. For Anderson and Gatignon (1986) and Barkema and Vermeulen (1998), experience would bring to MNEs knowledge of the best ways to access local assets, such as workforce, causing MNEs to be more prepared to analyze better acquisition opportunities.

Other earlier theoretical works have treated foreign sequential expansion as a kind of evolutionary movement subject to their competitive advantage over local firms to reduce the hazard of failure (Chang, 1995). The firms will first enter their core business in their foreign expansion. After, learning from early experience enable them to enter in noncore business or into areas of weaker competitive advantages. Delios and Beamish (1999) have also asserted that foreign investors initially hold small equity interests, in particular when they require complementary assets to exercise their activities abroad (such as natural resources possibly owned by local companies, with which MNEs would establish JVs). Such interests would increase as a result of the enhancement of specificity of the assets transferred to their subsidiaries and the international expertise of the MNE, as well as the institutional strengthening of the environment where they operate.

In turn, Harzing (2002) has added an important variable to the studies on the internationalization of companies, that is, the international strategy of the $M N E$, by segregating the strategies adopted into global (global operations and standardized global production) and "multi-domestic" (primarily competing in the domestic market of each host country). For the author, the strategy adopted would influence MNEs entry and expansion modes choices.

In contrast to theses traditional theories that still relied on the assumption that local complementary assets are always available and freely negotiated in host markets, Hennart (2009) has refuted MNEcentric theories and asserted that the MNE entry and expansion strategies also relies on the easy access and tradability of local assets. The author has stressed that local complementary assets have owners and that the access to such assets entails transactional costs, which impact MNEs entry and expansion choices.

Hennart has mentioned as examples of local complementary assets that affect the decisions made by MNEs: (i) location, quoting Wal-Mart, which faced problems in Germany since it was not allowed to acquire big plots of land, necessary for the establishment of its stores; (ii) distribution, whose access can be restricted due to the shortage of distributors or the poor quality of services; (iii) workforce, stressing that the access to such asset can be more difficult in markets comprising companies with large concentration of workers; (iv) regulatory licenses and permits, that can be obtained directly from local governmental agencies or negotiated among the sector companies; and (v) local consumer market and the relationship of consumers with specific companies. As one of the problems to be faced by MNEs in this sense, the author mentions the relationship of consumers with specific brands, whose solution would be the acquisition of such brands by new entrants.

Thus, and considering that, especially in emerging countries, markets are defective; and that entry and 
expansion modes adopted by MNEs in foreign markets relies on the efficiency of the local market in terms of negotiation of such local complementary assets, he proposed his Bundling Model, as shown in Figure 1.

\begin{tabular}{|c|c|c|c|}
\hline & \multicolumn{2}{|c|}{ Knowledge assets held by MNE } \\
\hline & & $\begin{array}{l}\text { Easy } \\
\text { to transact }\end{array}$ & $\begin{array}{l}\text { Difficult } \\
\text { to transact }\end{array}$ \\
\hline \multirow{2}{*}{$\begin{array}{l}\text { Complementary } \\
\text { assets held by } \\
\text { local owners }\end{array}$} & $\begin{array}{l}\text { Easy to } \\
\text { transact }\end{array}$ & Indeterminate & $\begin{array}{c}\text { Wholly-owned } \\
\text { affiliate } \\
\text { of the MNE }\end{array}$ \\
\hline & $\begin{array}{l}\text { Difficult } \\
\text { to transact }\end{array}$ & $\begin{array}{c}\text { Wholly-owned } \\
\text { operations of } \\
\text { local firm }\end{array}$ & $\begin{array}{l}\text { Joint Venture } \\
\text { between MNE } \\
\text { and local firms }\end{array}$ \\
\hline
\end{tabular}

Fig. 1

Optimal mode of foreign market entry ("Bundling Model") Source: Hennart (2009)

The author has also asserted that: (i) acquisition is the most efficient approach when local complementary assets cannot be separately acquired, but the market for firms is efficient; and (ii) MNEs with diversified activity choose to carry out acquisitions rather than greenfields (since they could overlap their diversified approaches with the most varied types of companies and activities, without necessarily changing them).

Hennart's theory, with respect to the market entry mode adopted by foreign investors, was tested in Brazil by Hennart, Sheng and Pimenta (2015), who concluded that the number of suppliers available and the concentration of the industry significantly affect the entry mode adopted by MNEs (if by way of greenfields or acquisitions or JVs or WOSs).

With respect to the subsequent expansion of MNEs in host countries, Hennart (2009) has asserted that the mode selected to expand host-market activities is also related to knowledge held by MNEs (and the costs to transact them) and the access to local complementary assets, refuting the traditional theories when affirming that MNEs expansion modes could differ from that proposed (which would give rise to the establishment of WOS) and could also be inverted, with a lower interest held by MNEs in cases where their knowledge would become easily negotiable but the access to local complementary assets not. The expansion of MNEs over time would depend on the evolution in efficiency for accessing local assets and transferring knowledge, as shown in Figure 2.

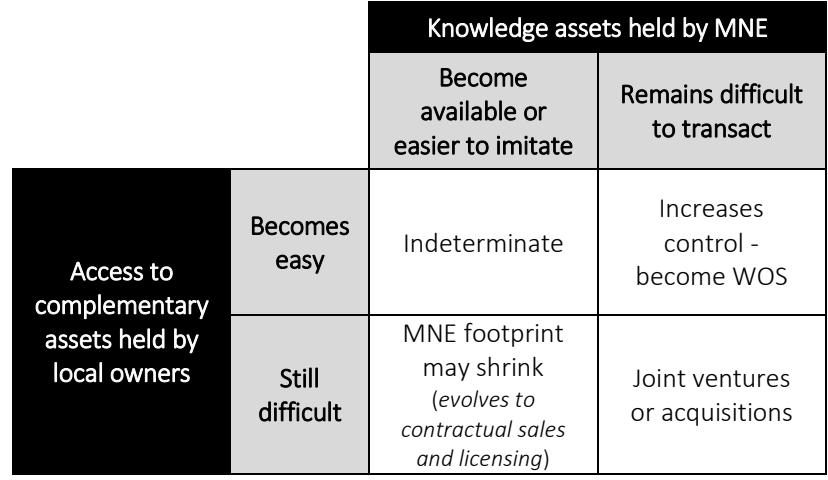

Fig. 2

Bundling Model applied to expansion

Source: Own elaboration using Hennart's propositions (2009).

Therefore, the expansion of MNEs would arise from changes in asset transaction costs of both sides. Hennart has also acknowledged that the complementary assets necessary for the performance of activities of MNEs vary according to their industry.

\subsection{Characteristics of the Brazilian market and regional differences}

MNEs activities and performance are affected by host country institutional factors, specially by those related to political and economic uncertainties, institutional inefficiencies and disparities (Liu, Gao, Lu \& Lioliou, 2016).

Brazil, one of the largest emerging market, was in 2015 the eighth biggest recipient of foreign investments in the world, a rank that highlights the significance of the Brazilian market for foreign investors (UNCTAD, 2016). Before the current economic crisis, in 2013, the country managed to be the fifth biggest recipient in the world (UNCTAD, 2014). However, factors such as complex regulation, bureaucracy and the delay of governmental agencies (both in terms of implementation of new activities, upon the granting of licenses and permits, and in terms of enforcement of the regulation), are perceived as problems faced by companies operating in the country. In this regard, Estrin and Prevezer (2011) make important considerations on problems faced by companies formally established in the country.

In the case of some industries, such as mineral extraction, power and petrochemical segments, highly regulated (depending on operating permits, license or concessions for exploitation), and historically concentrated (led by companies 
associated with the government, such as former government-owned Vale do Rio Doce, privatized in 1997, and Petrobras, still controlled by the federal government), the problems faced consists in true obstacles for the performance of such activities, in particular by foreign investors.

Within such context, the country is ranked $123^{\text {th }}$ (of 190 countries) in the current "Ease of Doing Business in Brazil" ranking, behind countries like Zambia and Honduras, which, coupled with the abovementioned factors, stresses the problems faced by MNEs to access local complementary inputs and to fully adapt their activities to the local context. It is also worth pointing out that the country is ranked $175^{\text {th }}$ in terms of "starting a business", $172^{\text {th }}$ in terms of "dealing with construction permits" and $181^{\text {st }}$ in terms of "paying taxes" (World Bank, 2017).

With regard to market for firms, notwithstanding the fact that the ownership structure of Brazilian companies is primarily concentrated and familyrelated, there are no legal prohibitions to the acquisition of companies, except for transactions that, owing to their size or stakeholders, should be submitted to the approval of the Brazilian administrative council for economic defense (Conselho Administrativo de Defesa Econômica $(A D E)$, and those requiring the approval of specific regulatory bodies, such as banks. In 2013, Brazil registered 812 transactions involving the purchase of noncontrolling, controlling or total ownership interest in the Brazilian market, of which 323 involved foreign companies (PWC, 2014). In 2016, the country registered 597 transactions, of which 255 involved foreign companies (PWC, 2016).

One of the oddest features of the Brazilian market is precisely the huge disparity between Brazilian regions (including social and economic indicators), which creates various "Brazils" inside one single country. In this sense, we may quote the article in "The Economist" magazine (2011), which compared Brazilian states with countries, based on its population, Gross Domestic Product (GDP) and GDP per capita. Whereas the Southeast region was compared to countries such as Hungary, Singapore or Poland, some states in the Northeast region were compared to Cambodia and even Afghanistan.

\section{Specific industry characteristics in Brazilian regions}

In their works, Oliveira Júnior (2006) and Ardissone (2009) conclude that the decision on the industrial location is intrinsically related to the characteristics of each industry, such as the presence of factors of production, tax incentives, salary costs, proximity with the market and existing plants. In this regard, we could cite recent cases of MNEs strategies in Brazil, such as the installation in 2013 of a Kimberly-Clark unit in the state of Bahia (Camaçari). The new unit was designed to expand the MNE's business in the North and Northeast regions, and its location was chosen due to the existence, in Camaçari, of some of Kimberly-Clark suppliers, located in the new region's "Polo Acrílico". The decision to focus on the Northeast region was also based on the rapid growth of the local consumer market (Gente e Mercado, 2011).

Despite some recent changes, the Brazilian industry is historically concentrated in the Southeast region, in particular in the cities of São Paulo, Belo Horizonte and Rio de Janeiro. Indeed, the Metropolitan Region of São Paulo only concentrated $15.8 \%$ of the jobs in the industry in 2007 (Saboia, 2013), and in 2010, the state of São Paulo was responsible for $30 \%$ of the totality of industrial jobs in Brazil (Sobrinho, Azzoni, 2015). Table 1 shows the share of each region in the Brazilian Gross Domestic Product (GDP) from 2003 to 2014.

Tab. 1

Brazilian regions participation in Brazilian GDP (2003-2014)

\begin{tabular}{|c|c|c|c|c|c|c|c|c|c|c|c|c|}
\hline \multirow{2}{*}{ Regions } & \multicolumn{12}{|c|}{ Participation in GDP (\%) } \\
\hline & 2003 & 2004 & 2005 & 2006 & 2007 & 2008 & 2009 & 2010 & 2011 & 2012 & 2013 & 2014 \\
\hline Brazil & 100 & 100 & 100 & 100 & 100 & 100 & 100 & 100 & 100 & 100 & 100 & 100 \\
\hline North & 4,8 & 4,9 & 5 & 5,1 & 5 & 5,1 & 5 & 5,3 & 5,5 & 5,4 & 5,5 & 5,3 \\
\hline Northeast & 12,8 & 12,7 & 13,1 & 13,1 & 13,1 & 13,1 & 13,5 & 13,5 & 13,3 & 13,6 & 13,6 & 13,9 \\
\hline Southeast & 55,8 & 55,8 & 56,5 & 56,8 & 56,4 & 56 & 55,3 & 56,1 & 56,1 & 55,9 & 55,3 & 54,9 \\
\hline South & 17,7 & 17,4 & 16,6 & 16,3 & 16,6 & 16,6 & 16,5 & 16 & 15,9 & 15,9 & 16,5 & 16,4 \\
\hline Central-West & 9 & 9,1 & 8,9 & 8,7 & 8,9 & 9,2 & 9,6 & 9,1 & 9,1 & 9,2 & 9,1 & 9,4 \\
\hline
\end{tabular}

Source: IBGE - Regional Accounts, 2012, 2014 
Only 6 out of the 25 main industrial mesoregions were located outside the South/Southeast axis in 2007 (Saboia, 2013). The South region showed a very peculiar industrialization process: it was initially developed by way of industries created by regional entrepreneurs, strongly influenced by immigrants and focused on agricultural raw materials.

On the other hand, the North and Northeast regions still show social and economic indicators comparable to those of developing countries and relatively low industrial and economic growth. North's industrialization derived from governmental plans and began upon the creation of the Manaus Free Trade Zone in 1967, but it still shows problems such as the distance from consumer centers and lack of transportation. The Central-West region has been changing its growth patterns over the past years; some companies were established in such region to carry out the on-site processing of cotton, soybean, corn, leather and meat, also attracting other service providers and input suppliers. Table 2 contains data on the share of regions in the gross added value at basic prices per economic activity, relating to 2012 .

\section{Tab. 2}

Regions' shares in the gross added value at basic prices per economic activity (2014)

\begin{tabular}{rcccc}
\hline \multirow{2}{*}{$\begin{array}{c}\text { Big } \\
\text { Regions }\end{array}$} & \multicolumn{3}{c}{ Share in the gross added value at basic prices } \\
\cline { 2 - 5 } & $\begin{array}{c}\text { Extraction } \\
\text { industries }\end{array}$ & $\begin{array}{c}\text { Transformation } \\
\text { industries }\end{array}$ & $\begin{array}{c}\text { Electricity, } \\
\text { gas and } \\
\text { water supply }\end{array}$ & Trade \\
\hline Brazil & 100 & 100 & 100 & 100 \\
North & 9,1 & 4,4 & 7,4 & 5,1 \\
Northeast & 6,3 & 9,1 & 16,3 & 15,7 \\
Southeast & 82,5 & 56,4 & 44,8 & 50,8 \\
South & 1,0 & 24,3 & 19,4 & 18,9 \\
Central-West & 1,2 & 5,7 & 12,1 & 9,4 \\
\hline
\end{tabular}

Source: IBGE - Regional Accounts, 2014

With respect to the business acquisition market, it should be pointed out that $68,6 \%$ of the 813 abovementioned transactions in 2013 were carried out in the Southeast region (PWC, 2014). In 2016, $64 \%$ of the 597 transactions were carried out in the Southeast region (compared to $2 \%$ in the North region, $4 \%$ in the Midwest region, $16 \%$ in the South region and $6 \%$ in the Northeast region). Only the state of São Paulo carried out $49 \%$ of the total transactions (PWC, 2016), equally showing the disparity between Brazilian regions (PWC, 2013).

Given these significant regional differences in the country, the penetration in new regions could pose new problems concerning the access by MNEs to complementary assets. Hence, in accordance with Hennart's model (2009), they would be inclined to carry out new acquisitions and JVs to access such complementary inputs and consolidate in local markets.

In an empirical econometric study of the entry mode chosen by firms investing in Brazil, Hennart, Sheng \& Pimenta (2015) found that the low number of suppliers (and, therefore, the low availability of raw materials and other inputs, such as electricity, gas and water supply in the regions North and Northeast, as shown in Table 2) represents difficulty in the access of complementary local inputs and affects MNE's strategies, causing them to establish JVs in their entry into new markets.

\section{RESEARCH DESIGN}

In order to analyze the expansion choices of MNEs and the possible factors behind such decision, we conducted a longitudinal study on the exploratorydescriptive nature, analyzing transactions carried out by the 10 major US MNEs operating in the country between 2004 and 2013, in particular in light of the Bundling Model designed by Hennart. We assumed that all these groups enjoy very mature local and global business and have learned from their own experience in operating in Brazil.

To this end, we are based on the following criteria: (i) inclusion in the sample of US MNEs only (the decision to restrict the analysis to one home country and one host country excludes possible cultural bias arising from one or another); (ii) delimitation of the period between 2004 and 2013 (also to mitigate a potential bias arising from the period analyzed); and (iii) analysis of transactions carried out in Brazil only, taking into account that this study is only interested in examining how the characteristics of the Brazilian market influence the decision-making process in connection with the expansion modes of MNEs in Brazil.

We selected the 10 major multinational groups whose capital originates from the United States operating in Brazil, according to the gross revenue ranking disclosed by Valor Econômico (Valor Grandes Grupos magazine). However, we excluded from the sample companies operating in the financial sector, since we understand that such sector has very specific characteristics, that could change some of the projected results. We also excluded the Mosaic group, since such group originated from a JV between 
Tab. 3

Groups, industries and concentration ratio C4 and C8 index (2014)

\begin{tabular}{cccc}
\hline Group and Year of Entry & Industry & C4 & C8 \\
\hline AES (1996) & Electricity production, distribution and supply & 19,6 & 32,2 \\
Alcoa (1965) & Mining and quarrying industry & 66,6 & 73,6 \\
Cargill (1965) & Basic metals & 19,2 & 26,8 \\
Dixie (1998) & Food insdustry & 10,5 & 15,1 \\
Dana (1957) e Plascar (2006) & Motor vehicles and autoparts & 14,3 & 21,8 \\
Dow (1956) e DuPont (1937) & Rubber and plastic products/Packages & 4,7 & 7,4 \\
Wal-Mart (1994) & Chemical and petrochemical & 7,2 & 12 \\
Whirlpool (1957) & Retail (Supermarkets) & 59,3 & 63,8 \\
\hline
\end{tabular}

Source: IBGE - Regional Accounts, 2014

Cargill group, which was already included in the sample, and IMC Global group. Consequently, we selected: Wal-Mart; AES, Cargill, Whirlpool, DuPont, DOW, Alcoa, Dixie Toga, Dana and Plascar.

\subsection{Data}

Data collection primarily was based on: the information disclosed in reports by the companies themselves; proceedings analyzed by CADE; Thomson Reuters' database on acquisitions and JVs; and data published by the IBGE (Instituto Brasileiro de Geografia e Estatística). We also collected information disclosed by the National Investment Information Network (RENAI), relating to the period between 2004 and 2013, comprising expansion and implementation investment projects.

In order to verify the major regional differences in the country and the characteristics of groups' operating sectors, we analyzed existing studies and collected data disclosed by specialized magazines and by national industries' associations, such as the Brazilian Association of the Chemical Industry (ABIQUIM), the Brazilian Supermarket Association (ABRAS), the Brazilian Packaging Association (ABRE), etc. We also checked the level of concentration of each industry (obtained from the IBGE, being understood that the higher the concentration the more difficult the access to complementary inputs would be). Tables 3 and 4 summarizes a few data relating to the MNEs and the industry of their core activities.

The transactions carried out by each one of the groups were classified as JV or WOS, and acquisition or greenfield. For purposes of simplification, acquisition means total or partial acquisition of the share capital of a given company, and greenfield is considered in a broad sense, meaning investments in new projects by companies rather than in the acquisition of existing structures. JVs represents interest in companies of up to $95 \%$ of total capital, sharing capital with other partners, and or WOS, interest in the subsidiary above $95 \%$ of total capital.

Finally, we verified if the transaction was carried out in the same Brazilian microregions where the MNE already operated, or if the transaction was carried out in a region where it did not operate yet (in other regions), if it was carried out within the core activity of the group and if it involved local companies/players or other MNEs operating in Brazil.

Tab. 4

Groups, industries and concentration ratio C4 and C8 index (2014)

\begin{tabular}{|c|c|c|c|c|c|c|}
\hline Group and Year of Entry & Industry & Growth 2008 & 2009 & 2010 & 2011 & 2012 \\
\hline AES (1996) & Electricity production, distribution and supply & 1,1 & 8,2 & 7,5 & 8,0 & 8,4 \\
\hline \multirow[t]{2}{*}{ Alcoa (1965) } & Mining and quarrying industry & $-2,7$ & $-26,1$ & 56,8 & 33,8 & $-15,3$ \\
\hline & Basic metals & 20,6 & $-23,7$ & 10,7 & 9,6 & 2,6 \\
\hline Cargill (1965) & Food insdustry & 24,4 & 10,4 & 4,5 & 19,2 & 14,2 \\
\hline Dana (1957) e Plascar (2006) & Motor vehicles and autoparts & 19,3 & $-3,3$ & 20,2 & 10,4 & 0,5 \\
\hline Dixie (1998) & Rubber and plastic products/Packages & 14,7 & 1,3 & 14,4 & 12,7 & 7,4 \\
\hline Dow (1956) e DuPont (1937) & Chemical and petrochemical & 13,8 & -5 & 2,5 & 12,8 & 12,9 \\
\hline Wal-Mart (1994) & Retail (Supermarkets) & 22,3 & 17,5 & 17,6 & 14,9 & 17,2 \\
\hline Whirlpool (1957) & Electrical machinery and apparatus & 18,6 & 3,9 & 14,6 & 5,6 & 9 \\
\hline
\end{tabular}

Source: Own elaboration, from IBGE (Annual Survey of Industry) and ANEEL data 


\section{ANALYSIS OF RECENT EXPANSION OF US MULTINATIONAL GROUPS IN BRAZIL}

The research conducted produced data relating to 106 transactions carried out by US multinational groups in Brazil within 10 years, of which 76 transactions were carried out through greenfield, 30 through acquisitions, 41 through JVs and 65 through WOSs. 101 were carried out inside the same region(s) where the groups already operate (also including in such category those transactions carried out nationwide, considering that, in such cases, the matter relating to the specific access to the complementary assets of a new region is not relevant) and 5 in other Brazilian regions, as shown in the Table 5 .

Based on all information obtained, on MNEs expansion theories (in particular the Bundling Model), on Brazilian nation- and region-wide context and also on the characteristics of each industry of the MNEs analyzed, we present a few considerations with respect to the results obtained.

\subsection{Transactions carried out in other regions}

Notwithstanding the fact that the large majority of transactions (101) was carried out inside the same region where the groups already operated, 5 expansion transactions were carried out in other Brazilian regions.

Given that Brazilian regions show considerable social, economic and cultural differences among each other, it is possible to assume that the entry in a new region would entail new accesses to the specific local complementary inputs of that region. Such complementary assets can be related both to the availability of resources and the size/growth of the local market and possible efficiency gains.

Considering that in the majority of the cases: (i) the individual access to such complementary assets may be very difficult for new players, owing to the national and regional characteristics already described; and (ii) such complementary assets would be embedded in companies that already operate in the region where the expansion is carried out, according to Hennart's Bundling Model, such new accesses would be achieved through acquisitions.

Indeed, it was possible to observe that the 5 transactions carried out in regions other than those where the multinational groups already operated involved acquisitions, as shown below:

(i) acquisitions by DOW of Agromen's corn production divisions in Brazil and of and Globe Metais, a silicon producer, one of the main raw materials used in DOW's products. In 2007, DOW, through its subsidiary DOW Agrosciences, has acquired $100 \%$ of Agromen Sementes Agricolas, Agromen's corn division, aiming the development, planting, processing and production of hybrid corn seeds. Agromen was located in the Southeast and Central-West regions and was up to then the biggest corn seed producer in the country.

DOW's strategy upon the acquisition was to find a vector for one of the genes produced by its Agroscience arm and strengthen its business in the corn market (including for purposes of export, aiming at producing seed-made biofuel). Through the acquisition, DOW has expanded its business in the sector and was ranked $3^{\text {rd }}$ in terms of market share in

Tab. 5

Transactions carried out within the same region and in other regions by MNEs

\begin{tabular}{|c|c|c|c|c|c|c|c|c|c|}
\hline \multirow{2}{*}{ MNES } & \multicolumn{4}{|c|}{ Same region(s) } & \multicolumn{4}{|c|}{ Other Region } & \multirow{2}{*}{ Total } \\
\hline & Greenfield & Acquisition & JV & WOS & Greenfield & Acquisition & $\mathrm{JV}$ & WOS & \\
\hline AES & 12 & 0 & 12 & 0 & 0 & 0 & 0 & 0 & 12 \\
\hline Alcoa & 10 & 2 & 4 & 8 & 0 & 0 & 0 & 0 & 12 \\
\hline Cargill & 21 & 14 & 12 & 23 & 0 & 0 & 0 & 0 & 35 \\
\hline Dana & 3 & 1 & 1 & 3 & 0 & 0 & 0 & 0 & 4 \\
\hline Dixe-Toga & 2 & 5 & 4 & 3 & 0 & 0 & 0 & 0 & 7 \\
\hline DOW & 7 & 2 & 3 & 6 & 0 & 2 & 0 & 2 & 11 \\
\hline DuPont & 4 & 0 & 2 & 2 & 0 & 0 & 0 & 0 & 4 \\
\hline Plascar & 2 & 1 & 1 & 2 & 0 & 0 & 0 & 0 & 3 \\
\hline Wal-Mart & 10 & 0 & 0 & 10 & 0 & 3 & 1 & 2 & 13 \\
\hline Whirl-pool & 5 & 0 & 1 & 4 & 0 & 0 & 0 & 0 & 5 \\
\hline Total & 76 & 25 & 40 & 61 & 0 & 5 & 1 & 4 & 106 \\
\hline
\end{tabular}

Source: Own elaboration, from IBGE (Annual Survey of Industry) and ANEEL data 
the country (GEEIN Unesp, 2007 and Revista Dinheiro Rural, 2007). Hence, it has quickly assumed an important position in a sector that was not one of its main operating sectors and obtained access to specific complementary assets not yet held by it.

In 2009, DOW also acquired $100 \%$ of Globe Metais Indústria (belonging to the Brazilian Camargo Corrêa group), a silicon producer, one of the main raw materials used in DOW's products. For DOW, the acquisition represented an opportunity to gain access to one of the main raw materials necessary for its production process. Indeed, the acquisition strategy was precisely to increase the efficiency of its production process, by enabling a "more efficient and stable" supply of silicon metal (Fator Brasil magazine, 2009).

It is possible to describe as factors that gave rise to this acquisition by DOW: (i) the target was one of the main producers of silicon, the basic raw material of its products (access to competitive raw material is described as one of the major challenges in the sector - ABIQUIM, 2013); and (ii) Globe Metais was located in another region, in the Northern part of Brazil (Pará), which is considered ideal for the production of silicon due to the existence of more deposits at the site and availability of electric power. The production of silicon is historically concentrated in the state of Minas Gerais, in the Southeast region. In light of the foregoing, it is possible to affirm that DOW consummated such acquisition so as to facilitate its access to complementary assets, available in a different region.

(ii) acquisitions by Wal-Mart of the Bompreço supermarket chain and partnership with Unibanco for the development of Hipercard and acquisition of Sonae chain. After entering Brazil through a JV with Lojas Americanas in 1995, which represented for the group "a security against political risks" and for its Brazilian partner "technology and know-how" (Minadeo and Camargos, 2009), and, after acquiring, in 1998, the remaining ownership interest (becoming a WOS), Wal-Mart quickly consolidated its operations in the competitive supermarket sector, characterized by rapid growth, consolidation and increasing participation of foreign groups, with many mergers and acquisitions over the past years (ABRAS, various years).
The group has initially concentrated its activities in the Southeast region. In 2004, it has expanded its operations and started its expansion and consolidation in other Brazilian regions, by acquiring from Dutch Ahold the Northeastern Bompreço chain (which itself also had a recent past of acquisitions). Such acquisition enabled Wal-Mart to penetrate the market in the Northeast region - which was more concentrated than national average and historically controlled by local traditional chains, such as Paes Mendonça, former owner of Bompreço. After the purchase of Bompreço, Wal-Mart accounted 163 stores and its annual revenues grew from $\mathrm{R} \$ 1.7$ billion to R\$5 billion (Minadeo and Camargos, 2009).

The acquisition also resulted in a partnership with Unibanco, a Brazilian bank, for the operation of the Hipercard credit card business, privileging the performance by Wal-Mart of activities other than its core activity.

In 2005, the group acquired stores from Portuguese group Sonae, which enabled its penetration in South region's market. By then, Sonae had already carried out various acquisitions, including traditional family-managed chains in the region, helding an important position in that local market. After such acquisition, Wal-Mart assumed in 2006 the second position in the sector in Brazil, outshining other foreign chains long established in the country, such as Carrefour.

Therefore, acquisitions represented for Wal-Mart valuable opportunities to obtain privileged access to the complementary assets necessary for its expansion in the South and Northeast, by means of the acquisition of chains that were already established in their local markets (which, since it was traditionally concentrated and up to then controlled by local chains, posed obstacles for new players, e.g., in terms of access to consumers and local suppliers). If carried out otherwise, the access to local assets could be time-consuming (big disadvantage in markets that show quick growth, such as the supermarket sector) and burdensome.

Citing the specific case of Bompreço's acquisition, it is worthy to mention that, being the absolute leader in its sector the Northeast, Bompreço was considered a barrier to other participants entry, specially due to its efficient logistics chain, consolidated relationship with suppliers, strong brands (such as Bompreço itself, Bomclube and Hipercard) and strategic locations (Pinto, 2000). The local consumer market 
had such a strong identification with the Bompreço brand that even today Wal-Mart's stores remain under the Bompreço brand.

Hence, analyzing the case of Wal-Mart under Hennart's theory, acquisition was chosen since the complementary assets needed (such as the specific knowledge of the local consumer market and suppliers) were difficult to access and were embedded in the companies acquired. It is also possible to affirm that total acquisition was preferred to JVs because the group acquired companies in its own segment (in which it already had extensive knowledge and other important assets). As such, the assets acquired could be easily integrated with other assets and knowledge already held by Wal-Mart (they had "Modularity", according to Hennart).

\subsection{Transactions carried out in the same region}

\section{Greenfields/WOSs}

Under Hennart's Bundling Model, it is possible to conclude that transactions carried out by MNEs inside the same region where they already operate would tend to be carried out through greenfields, since it would not be necessary to "gain" new accesses to local complementary inputs (often embedded in already operating companies). Likewise, since MNEs knowledge tend to remain difficult to access, but local complementary assets not, MNEs would be inclined to make investments through WOSs.

In fact, it is possible to note that the large majority of the transactions carried out by the groups in the regions where they already operated, in the period analyzed, was carried out through greenfields (76) and WOSs (61).

In the case of Wal-Mart, after its initial JV and acquisitions in the Northeast and South regions, and after gaining experience and consolidating its activities in the local markets, becoming an important player in the sector on a nationwide basis, it started to exclusively carry out greenfields and WOSs, upon the opening of new units (including branches and distribution centers in various cities) and expansion of its operating lines.

Dixie-Toga, Dana and Whirlpool groups, which started to operate through JVs with domestic groups, acquired afterwards the remaining stake in the companies and changed their activities into WOSs. For example, Dana started to operate in Brazil through an acquisition/JV, after acquiring, in 1957, a stake in Albarus, a renowned Brazilian company operating in the autoparts sector. Ten years later, it acquired the company's shareholding control. The Bundling Model could be applied to those cases in the sense that, in order to access complementary assets held by other groups, the MNEs have entered into partnerships with them and, thereafter, with the access to complementary assets already consolidated and facilitated (and on total possess of its own knowledge), they elected to fully assume the business from their partners.

AES started to operate in Brazil through a series of acquisitions and JVs in the Brazilian electric power sector, highly regulated and recently subject to a phase of transformations and privatizations. Such acquisitions included: part of state-owned Light in 1996 (in a consortium with French EDF and US Houston Industries Energy); part of CEMIG in 1997 (in another consortium with US Southern Eletric and Brazilian bank Opportunity); Companhia CentroOeste de Distribuição de Energia Elétrica in 1997; and the shareholding control of Eletropaulo Metropolitana in 1998 (in a consortium with Houston, EDF and Brazilian Companhia Siderúrgica Nacional). Finally, in 2003 it has created the holding Companhia Brasiliana de Energia, which controls the group business, in which BNDESPAR is the other shareholder

After such acquisitions, which enabled AES to access the local assets needed (especially critical and specific regulatory requirements, such as permits for the exploration and distribution of power), and after consolidating its activities in the country, AES chose to carry out its transactions in the analyzed period through greenfields.

\section{Acquisitions/JVs}

Notwithstanding the explanations above, we verified that some of the groups, even when expanding inside the regions where they already operated, established JVs and carried out acquisitions. Indeed, 25 transactions carried out between 2004 and 2013 inside the same region were acquisitions and 40 were JVs.

Such acquisitions and JVs evidences that, besides the region, other factors can be additionally described as drivers for the expansion alternatives of MNEs. More specifically, based on the analysis of the total context of transactions carried out, we noted 
that other factors can prevent the access of MNEs to the complementary assets needed, leading companies to carry out acquisitions and/or JVs to access such assets, such as, for example:

(i) problems underlying the operating sectors, such as sectors "pressured" between suppliers and consumers, or regulated (that require the obtaining of licenses and permits). We can here mention the case of Dixie-Toga (Bemis), which had consolidated its activities in the domestic market through acquisitions and JVs, such as the establishment of Laminor together with Finnish Huhtamaki and the acquisition of packaging divisions from other MNEs (such as Alcoa and Alcan in 2004 and 2010). This could be explained by the sector in which it operates - being the "pressured" link of the chain, between suppliers and customers with high bargaining power (FIPE, 2008) - where raw material suppliers and the consumer/distributor network would be complementary assets difficult to access by new players, leading them to consolidate through acquisitions and JVs.

We could also mention the case of AES which, operating in a highly regulated sector, penetrated Brazilian markets through acquisitions and JVs with Brazilian and foreign groups; and the case of Alcoa, which, in order to operate in the power sector, established JVs (Machadinho Consortium, Estreito Energia-CESTE and Maesa) and, to consolidate some activities in its own sector, has invested in JVs, such as the Alumar Consortium.

(ii) engagement of the MNEs in new activities, other than its core activity. We can here cite the transactions carried out by Cargill, in 2013 the $5^{\text {th }}$ largest exporter among the companies located in Brazil (MDIC/SECEX, 2013) and the company that carried out more acquisitions and transactions among the multinational groups analyzed.

When Cargill invested in activities other than its core activities, carried out acquisitions and JVs. It penetrated in the sugar and alcohol markets through acquisitions and JVs (with Brazilian Moema in 2006; with Canagril, after the acquisition of part of CEVASA in 2007; with Moema and other suppliers in Itapagipe plant; and also with Brazilian USJ group) and acted likewise in the export business (in TIS, establishing a JV with Brazilian Crystalsev and Ultra; in Terminal Exportador de Álcool de Santos, acquired a stake in a JV with Cosan and Crystalsev; and in Terminal
Exportador do Guarujá, in a JV with French Louis Dreyfus).

It should be mentioned again the transactions carried out in the power sector by Alcoa, and also: by DOW, for purposes of consolidation in the corn production sector (upon acquisition of Agromen and Coodetec); and by DuPont, which established a JV with a foreign group (Bunge) for the export and import of commodities.

Likewise, companies that operate in sectors with a higher level of concentration (the case of mineral extraction and metallurgy, electric power, supermarket and home appliances, represented by Alcoa, AES, Wal-Mart and Whirlpool, respectively), in expansion performed inside the sector and region in which they primarily operate, it was also possible to note a trend in the sense of carrying out acquisitions and establishing JVs to penetrate and consolidate in their core industries. After granting a leading position in the market (and already having full access to local complementary assets), the MNEs started to carry out greenfield investments.

It is also possible to observe that, even maintaining their own characteristics (considering its FSAs) and continuing to operate in the same region where they already operate, the MNEs can change their strategies, as a result of the characteristics of the markets in which they operate and the ease or difficulty to access the local complementary assets needed.

\subsection{Other results}

Transactions carried out by some of the groups also provided evidence to traditional theories, in the sense that the increase in the experience of the MNEs in the host country would also increase its commitment, leading them to expand through WOSs. In such sense, we may cite the cases of Dixie-Toga, Dana, Wal-Mart and Whirlpool, which started to operate through JVs and, thereafter, acquired the remaining stake in the companies and changed their activities into WOSs. However, such characteristic was only noted in those 4 groups, and in other cases, groups operating in Brazil for a long time continued to establish JVs (such as Cargill).

Such results do not invalidate the evidence about the application of Hennart's theory. In fact, it is possible to also state that the 2 principles are, in those cases, complementary - the experience in the 
host country would facilitate the access to local complementary assets, enabling the MNEs to establish WOSs; for this reason, both theories are applicable.

With respect to Harzing's theory (2002), we noted that companies with a more "global" production in fact show some characteristics during their expansion process that differentiate them from other "multidomestic" companies. Companies such as Alcoa, Cargill, DOW and DuPont, which carry out more export transactions and exercise globalized activities, are inclined to carry out transactions (JVs and acquisitions) on a worldwide basis (or region-wide, in the Americas, Europe, etc.), impacting directly or indirectly their transactions in the host country. However, based on the analysis conducted, it was not possible to confirm the theory that such companies would be inclined to make greenfield investments or vice versa, or would be inclined, during their expansion process, to "return" to the preferred expansion method.

\section{CONCLUSION}

We found evidence that support for the Bundling Model (Hennart, 2009) in Brazil. Brazilian regional differences are relevant for MNEs sequential expansion decision even if they own large previous experience in the country. Most expansion transactions carried out in "new" Brazilian regions involved acquisitions. Considering that the entry in a new region would require MNEs to "gain" new access to complementary assets, and assuming that these assets were embedded in other companies already operating in the market (and could be easily integrated to other MNE's assets), the results indicate that acquisition was chosen due to the specific characteristics of the Brazilian market, especially for the huge differences between Brazilian regions.

For expansions carried out within the regions in which MNEs already operate, we noticed that MNEs are inclined to make greenfield investments since, being already established in the region, they would not be required to "gain" new accesses. Other factors, however, can also prevent the access of MNEs to local complementary assets, such as difficulties inherent to the different industries and the engagement of the MNEs in new activities other than its core activity, causing companies to choose to carry out acquisitions and/or JVs.
Specifically, in the case of JVs, we remarked that the counterparty of the JVs established by the MNEs to enable their access to local complementary assets is not always represented by domestic groups; such JVs were also established with other foreign groups with previous access to the local complementary inputs.

On the other hand, based on the results obtained, we cannot assert that the traditional theories (with respect to which the period of experience of the MNEs would influence its commitment in the host countries and lead them to establish WOSs) were confirmed, since it was possible to make such assertion only with respect to 4 of the cases (DixieToga, Dana, Wal-Mart and Whirlpool). Such result also shows that MNEs expansion modes are much more related to the difficulty or ease to access the necessary complementary assets, as predicted by Hennart (2009), than to its experience considered alone.

Furthermore, it was possible to note that companies with a more global and "multi-domestic" production, as defined by Harzing (2002), indeed show different strategies upon their expansion; however, it is not possible to assert that such differentiation would lead to more acquisitions or greenfields by one or another.

Finally, this study has some limitations. We discussed earlier learning experience, but we did not differentiate the form of these experiences within the 10 major US major groups in Brazil. For example, DOW started to operate in Brazil in 1956, and DuPont, in 1937 (Table 3), whereas Plascar only started to be controlled by MNEs in 1995 (initially by other foreign groups and, in 2006, by US IAC group). We also did not fully used quantitative methods to discuss more local complementary asset variable like regional market concentration, which could reach more wide-ranging conclusions on MNEs expansion in Brazil and be applied to other countries with similar characteristics (emerging countries, with continental size and significant regional disparities).

\section{REFERENCES}

- Agência Nacional de Energia Elétrica - ANEEL. Informações Gerenciais (Junho/2014). Retrieved from: $<$ http://www.aneel.gov.br/arquivos/PDF/Z_IG_Jun14.p df $>$. Accessed 11/10/2014. 
- Anderson, E., \& Gatignon, H. (1986). Modes of foreign entry: a transaction cost analysis and propositions. Journal of International Business Studies.

- Ardissone, M. S. (2009). Mudança na distribuição espacial das atividades industriais por microrregião no período 1996/2005. PhD Dissertation - Instituto de Economia, Universidade Federal do Rio de Janeiro, Rio de Janeiro.

- Associação Brasileira da Indústria Química - ABIQUIM. O desempenho da indústria química brasileira, Reports. Various years.

- Associação Brasileira de Embalagens - ABRE (2013 e 2014) Estudo Macroeconômico da Embalagem ABRE/ FGV. Retrieved from: <http://www.abre.org.br/setor/dados-de-mercado/>. Accessed 11/24/2014.

- Associação Brasileira de Supermercados - ABRAS (2013) - Ranking ABRAS. Rerieved from: <http://www.abras net.com.br>. Accessed in July, October and November 2014.

- _ Revista Superhiper, São Paulo: various issues.

- Associação Nacional dos Fabricantes de Veículos Automotores - ANFAVEA (2014). Anuário da Indústria Automobilistica Brasileira. Retrieved from: $<$ http://www.anfavea.com.br/anuario.html $>$. Accessed $11 / 25 / 2014$.

- Barkema, H.; Vermeulen, F. (1998). International expansion through start-up or acquisition: A learning perspective. Academy of Management Journal, v. 41, n. 1, pp. 7-26.

- Chang, S. (1995). International expansion strategy of Japanese Firms: Capability Building Through Sequential Entry. Academy of Management Journal, v. 38, n. 2, pp. 383-407.

- Delios, A., Beamish, P.W. (1999). Ownership strategy of Japanese firms: Transactional, institutional, and experience influences. Strategic Management Journal, 20 (10), pp. 915-933.

- Economist. Compare-cabana - Comparing Brazilian states with countries (Which countries match the GDP and population of Brazil's states? Retrieved from: <http://www.economist.com/content/comparecabana>. Accessed 10/20/2011.

- Estrin, S.; Prevezer, M. (2011). The role of informal institutions in corporate governance: Brazil, Russia, India, and China compared. Asia Pacific Journal of Management,v.28(1),pp.41-67.

- Fundação Instituto de Pesquisas Econômicas - FIPE (2008). Setor de transformados de plásticos: caracterização, relevância, e sugestões de medidas de política produtiva para estimular a competitividade FIPE. Retrieved from: $<$ http://www.abief.com.br/palestra.php $>$. Accessed $11 / 25 / 2014$

- Gente e Mercado (2012). Kimberly-Clark investirá R\$ 250 milhões na Bahia até 2014. Retrieved from: <http://www.genteemercado.com.br/kimberly-clarkinvestira-r-250-milhoes-na-bahia-ate-2014/>. Accessed 01/10/2014.

- Grupo de Estudos em Economia Industrial - GEEIN Unesp (2007). Após compra, Dow deve dobrar fatia em milho. Retrieved from: <http://geein.fclar.unesp.br/jornais_det.php?codigo=7 563>. Accessed 12/01/2014.

- Global Business Reports (2011). Relatório da Global Business Reports para Engineering \& Mining Journal. Portuguese Version issued by Departamento Nacional de Produção Minerária (DNPM). Retrieved from: <http://www.dnpm.gov.br/mostra_arquivo.asp?IDBanc oArquivoArquivo=6150 $>$. Accessed 11/10/2014.

- Harzing, A.-W.(2002). Acquisitions versus greenfield investments: International strategy and management of entry modes. Strategic Management Journal, 23(3), pp.211-227.

- Hennart, J. F. (2001). Theories of the multinational enterprise. In Oxford handbook of international business. Oxford: Oxford University Press, pp. 127-149.

(2009). Down with MNE-centric theories! Market entry and expansion as the bundling of MNE and local assets. Journal of International Business Studies, n. 40, pp. 1432-1454.

- Hennart, J. M. A., Sheng, H. H. \& Pimenta, G. (2015). Local complementary inputs as drivers of entry mode choices: The case of US investments in Brazil. International Business Review.V. 24, P.466-475.

- Instituto Brasileiro de Geografia e Estatística - IBGE (2012, 2014). Contas Regionais. 2014 . Pesquisa Industrial Anual - Empresa, 2007-

- Estatísticas do Cadastro Central de Empresas, 2011.

- Johanson, J., Vahlne, J.-E (1977). Internationalization process of firm - model of knowledge development and increasing foreign market commitments. Journal of International Business Studies, 8(1), 23-32.

- Liu, X., Gao, L., Lu, J., \& Lioliou, E. (2016). Environmental risks, localization and the overseas subsidiary performance of MNEs from an emerging economy. Journal of World Business, v. 51(3), pp. 356-368.

- Minadeo, R; Camargos, M.A.(2009). Fusões e aquisições no varejo alimentar: uma análise das estratégias de entrada e crescimento do Carrefour e Walmart no mercado brasileiro. Revista de Ciências da Administração, Florianópolis, v. 11, n. 24, pp. 102-135, maio/ago.

- Oliveira Júnior, M. (2006). Aglomeração espacial e eficiência industrial: Um estudo a partir da evolução da produtividade nos municípios brasileiros de 1970 a 1996. 2006. PhD Dissertation. Instituto de Economia, Universidade Federal do Rio de Janeiro, Rio de Janeiro.

- Pinto, C. D.(2000). O Processo de Internacionalização e As Estratégias Competitivas no Varejo: O Caso 
Bompreço. Dissertation. Faculdade de Ciências Econômicas, Universidade Federal da Bahia, Salvador.

- PWC (2014). Relatório PWC Brasil de Fusões e Aquisições no Brasil - Dezembro de 2014. Retrieved from: <http://www.pwc.com.br/pt/publicacoes/servicos/asse ts/fusoes-aquisicoes/fusoes-aquisicoes-dezembro2014.pdf>. Accessed 05/21/2015.

- PWC (2016). Relatório PWC Brasil de Fusões e Aquisições no Brasil - Dezembro de 2016. Retrieved from: <http://www.pwc.com.br/pt/publicacoes/servicos/asse ts/fusoes-aquisicoes/2016/pwc-fusoes-aquisicoesdezembro-2016.pdf >. Accessed 07/01/2017.

- Revista Dinheiro Rural (2007). Em busca do milho perdido. Retrieved from: $<$ http://revistadinheirorural.terra.com.br/secao/agrone gocios/em-busca-do-milho-perdido>. Accessed $12 / 01 / 2014$

- Revista Fator Brasil (2014). Dow Corning adquire fábricas de silício nos Estados Unidos e Brasil. Retrieved from: $<$ www.revistafatorbrasil.com.br>. Accessed 10/12/2014.
- Saboia, J. (2013). A continuidade do processo de desconcentração regional da indústria brasileira nos anos 2000. Nova economia, Belo Horizonte, v. 23, n. 2.

- Sindicato Nacional da Indústria de Componentes para Veículos Automotores - SINDIPEÇAS. (2014). Anuário Desempenho do Setor de Autopeças, 2014. Retrieved from:<http://www.sindipecas.org.br/home/\#.VHsRSTH F_T8>. Accessed 11/23/2014.

- Sobrinho, E.M.G, Azzoni, C.R. (2015). Aglomerações Industriais Relevantes do Brasil em 2010. Revista Brasileira de Estudos Regionais e Urbanos. Vol. 09, n.1, pp. 1-18.

- United Nations Conference on Trade and Development - UNCTAD (2014, 2016). World Investment Report. Retrieved

from:<http://unctad.org/en/Pages/DIAE/World\%20Inve stment\%20Report/World_Investment_Report.aspx>. Accessed in 03/05/2015 and in 07/01/2017.

- Valor Econômico. Anuário Valor Grandes Grupos. São Paulo, n. 2-12, $2004-2013$.

- 39. World Bank (2017). Doing Business. Retrieved from: <português.doingbusiness.org/rankings>. Accessed: 07/01/2017.

\section{About the authors}

- Juliana Carvalho Sampaio Tourinho is Lawyer, graduated in the Federal University of Bahia (UFBA), with a Specialization's degree in Corporate Law from Pontifical Catholic University of de São Paulo (PUC-SP) and a Master's degree in Economics from the São Paulo School of Economics of Fundação Getúlio Vargas (EESP-FGV).E-mail: jsampaio82@gmail.com

- Hsia Hua Sheng hold a Doctor's Degree in Business Administration (concentration: Finance) from FGVEAESP. Professor and consultant in finance. Interested in: Multinationals; Foreign Investments and Business Finance; Risk Management. She also is Professor of Finance at FGV-EAESP and UNIFESP EPPEN.E-mail: hsia.sheng@fgv.br 


\title{
Escolhas do modo de expansão: O caso de uma Multinacional Americana no Brasil
}

\author{
Juliana Carvalho Sampaio Tourinho ${ }^{A}$ e Hsia Hua Sheng ${ }^{B C}$ \\ ${ }^{A}$ Escola de Economia de São Paulo da Fundação Getúlio Vargas - EESP/FGV, São Paulo, SP, Brasil \\ ${ }^{B}$ Escola de Administração de Empresa de São Paulo da Fundação Getúlio Vargas - EAESP/FGV, São Paulo, SP, Brasil \\ ${ }^{C}$ Escola Paulista de Política, Economia e Negócios da Universidade Federal de São Paulo - EPPEN/UNIFESP, SP, Brasil

\section{DETALHES DO ARTIGO}

\section{Histórico do artigo:} \\ Recebido em 30 de agosto de 2016 \\ Aceito em 10 de julho de 2017 \\ Disponível online em 31 de agosto de 2017 \\ Sistema de Revisão "Double Blind Review" \\ Editor científico: \\ Ilan Avrichir

\section{Palavras-chaves:} \\ MNE \\ Modos de Expansão \\ Teoria dos Ativos Complementares \\ Ativos Complementares Locais

\begin{abstract}
RESUMO
A teoria tradicional dos modos de expansão argumenta que a experiência local pode contribuir com as organizações multinacionais (MNEs) de forma a promover maior conhecimento das particularidades do mercado local, mitigando seu risco de expansão local e escolhendo sua forma de entrada entre uma subsidiária greenfield e integral. No entanto, os insumos complementares locais se tornam relevantes nesta decisão de expansão se os ativos complementares locais nem sempre estiverem disponíveis e negociados livremente (Hennart, 2009). Este artigo analisa a decisão de expansão sequencial feita por dez relevantes multinacionais americanas de grande porte com experiência de atuação no Brasil entre 2004 e 2013, identificando os possíveis multinacionais e suas diferenças entre as interregiões brasileiras. Destacam-se as seguintes evidências em apoio ao modelo de Hennart Bundling: i) a experiência das multinacionais no Brasil nem sempre aumenta o compromisso das multinacionais nos países hospedeiros através do estabelecimento de novas subsidiárias integrais; ii) as multinacionais norte-americanas realizam aquisições quando precisam se estabelecer em uma nova região com significativa diferença de desenvolvimento econômico local de onde a MNE já operou; iii) adicionalmente, fatores regionais brasileiros, como a concentração, o crescimento e as características intrínsecas das indústrias são determinantes às aquisições e às escolhas de joint ventures.
\end{abstract} \\ motivos para essa decisão, bem como considerando as teorias de expansão das
}

(C) 2017 Internext | ESPM. Todos os direitos reservados!

To cite this article:

Tourinho, J. C. S. and Sheng, H. H. (2017) Expansion Mode Choices: The case of US Multinationals in Brazil, 12 (2), 31-44. DOI: http://dx.doi.org/10.18568/1980-4865.12231-44

To access this article: $\mathrm{http}: / / \mathrm{dx}$.doi.org/10.18568/1980-4865.12231-44 